\title{
Using Newspapers and Advertisement as a Focus for Science Teaching and Learning
}

\author{
Hakan Akcay ${ }^{1}$, Hasan Ozgur Kapici ${ }^{1, *}$, Robert E. Yager $^{2}$ \\ ${ }^{1}$ College of Education, Yildiz Technical University, Istanbul, Turkey \\ ${ }^{2}$ College of Education, University of Iowa, USA
}

Copyright $\mathrm{O} 2017$ by authors, all rights reserved. Authors agree that this article remains permanently open access under the terms of the Creative Commons Attribution License 4.0 International License

\begin{abstract}
The purpose of this article is to provide a brief literature review and useful suggestions for using advertisements as tools for organizing and accomplishing science teaching and learning. Newspapers and advertisements can be used as a context for developing scientific literacy and for promoting the development of critical thinking skills, through questioning, creating flexible course content, and exploring science beyond the classroom.
\end{abstract}

Keywords Science Education, Newspaper, Lesson Activity, Teaching, Learning

\section{Introduction}

The goal of science education is to develop understanding of science and technology. Project 2061: Science for All Americans and the National Science Education Standards, two major national projects in USA, are being developed and designed to increase student interest in science and to enhance their scientific literacy, by focusing on re-designing and restructure what and how science is taught in our schools. They have common goals, which are to develop scientific literacy and to offer visions for change needed for current reforms to succeed. Scientific literacy entails being able to read with understanding articles about science in the popular press and to engage in social conversations about the validity of conclusions and recommendation offered $[1,2]$.

\section{Scientific Literacy as a Goal of Science Education}

School science programs emphasize that students should achieve scientific literacy, which is defined as the knowledge and understanding of scientific concepts needed in daily living. The National Science Teacher Associations has declared that a scientifically literate person is one who can ask and/or suggest answers to questions derived from curiosity about everyday life experiences. Standards specifically indicate that scientific literacy entails being able to read with understanding articles about science in the popular press and engage in social conversations about the validity of the information offered [2].

Scientific literacy enables students to not only use scientific principles and processes in making personal decisions but also enables them to participate in discussions about scientific issues that affect society. Scientific literacy increases many skills that students use in everyday life, like being able to solve problems creatively, thinking critically, working cooperatively in teams, and using technology informatively and effectively. Understanding scientific knowledge and processes contributes in essential ways to developing these skills. It is important to develop scientific literacy within classrooms because the goal of science education is to create scientific literacy, which includes an understanding of the nature of science and the role of science in society and in personal life [2].

\section{Science Related Issues in the Media}

All local, national and international newspapers often report about the new medical, scientific, and technological advances and discoveries as well as their uses and roles in reshaping human life and society. While the depth and the breadth of covering these types of topics vary from newspaper to newspaper and from region to region, many of the newspapers also devote specific section in a particular day of the week for covering these topics. For many people within the society, this is the main sources of scientific and technological information to help them to be connected and become scientifically aware of what is going on scientifically around them. But newspapers' covers of scientific and technological news and information are important beyond just this. Educationally speaking, newspaper articles that related to socio-scientific issues offer a context for developing students' knowledge and skills often associated with citizenship education. This is a good foundation for 
students interested in exploring science after their study because they will gather much information form newspapers and magazine [3]. Illustrating the real need for information and skills provides a motivation for learning which is often missing when the textbook is central or when the sequence of the units is determined, not by real events, but instead by an arbitrary set of pre-ordained materials, ideas, and historical events [4].

Newspapers and magazines provide a means of extending science discussions and the results of instruction beyond the classroom. In many instances, the reliance upon the popular press for ideas, initial information, and contradictions all provide a stimulus for greater involvement of family and friends as well as experts-often from very varying perspectives. Therefore, the science curriculum should be designed to enhance coverage of science-related issues in the media in order to improve student understanding of science. Students have the opportunity to observe and participate in the process by which events and ideas become news, improve their communication skills by learning to describe issues in media.

The following statements regarding the advantages of using newspapers and advertisements in science instruction provide reasons for using the popular press as a source for ideas and issues as contexts for improved student learning. These include:

- Starting science teaching with popular advertisements or very recent relevant newspaper article results in more curiosity, more questions, and a more unique learning and teaching environment;

- Students can relate science to the everyday news that they hear or read;

- Using the popular press can assist students in making informed decisions on whether the news or advertisements are correct or incorrect; and then discuss how to improve it scientifically.

- Using the popular press can improve students' thinking skills;

- Using newspapers and magazines can increase students' interest and motivation by providing study materials relevant to their lives;

- Using the popular press can prepare students for active citizenship practices in their communities;

- Using the popular press can enhance teachers' interest in new teaching techniques and sources for help in individual classrooms;

- Using the popular press can involve schools in the lives of people and the problems of the local communities they serve;

- Using the popular press can improve relations with and involvement of the families of students;

- Using the popular press can demonstrate practical applications of skills and concepts presented in school curriculum at all levels;

- Using the popular press can update and extend information contained in textbooks;
- Using the popular press can be fun;

- Using the popular press can motivate student learning;

- Using the popular press can introduce and encourage lifelong love of reading;

- Using the popular press can provide attractive classroom learning environments and provide opportunities to explore new educational approaches and resources that teachers may not have tried before [5].

\section{Strategies for Classroom Action}

Advertisements and news reports can be applied in several ways within science classrooms. First, the use of the popular press as an activity can be accomplished to help promote and exemplify scientific literacy for use in the real world (including life outside of school). Having students find falsified advertisements or nonscientific articles in the popular press can help students attain scientific literacy. The use of the information and practice with inquiry skills is basic to science itself and can be undertaken for use with almost every news report in daily newspapers.

Using newspapers in science classrooms helps students enhance their written and oral skills when newspapers are used to facilitate pedagogical activities that stress the importance of communication, to give students opportunities to discuss the scientific issues in science classes, and to create active learning environment in which students take control of their learning [6]. Active learning entails student centered classrooms with assignments that engage students in higher order thinking skills [7].

Finding advertisements and articles in the popular press can make students more aware to the scientific world around them while showing them the importance of raising questions about that world. Still another way is that it aids assessing the science in general content of advertisements, talking with the students about how they relate to science or specific science areas such as biology, physics, chemistry, and the natural environment. Opposing suggestions and claims that can be found add to the learning process. To address the science content that is missing from the advertisements and determine what more information students need to make informed decisions about the content in advertisements are important and again represents use of science in daily living. For example, diet advertisements or other advertisements that relate to health can be used as introductions to health or nutrition units. They can suggest questions for students regarding the nutritional content that various foods contain. The ethics of the advertisements could be debated within the classroom. Advertisements and articles in the popular press can create many opportunities for discussion that illustrate real science- not just typical "textbook" topics which often have no personal relevance. Finding the information on the internet is easy but how many people really research products before purchasing them. And, 
is the information from the internet always accurate and consistent? Teachers may ask students to find drug advertisements by using the web. It can be a fun and interesting project for students to undertake their own drug to research and to share the findings with the whole class, reinforcing the research process within their daily lives.

If teachers can learn to use the popular press more effectively as a source for scientific information (and/or misinformation), student' motivation and interest in science classrooms could be increased. Further, it could lay a better foundation for the future understanding of scientific, and science-based, issues [8].

The following cases define how students explored their thoughts and investigations through use of newspaper articles in science classrooms.

Case 1: This newspaper article appeared in Washington Post on 3 January 2003. Read it carefully and then answer the following questions.

Table 1. Scientists' Report about Orangutan "Culture"

The orangutans in central Borneo like to ride falling trees to the ground for fun. The orangutans in western Borneo, on the other hand, express annoyance by making a loud kissing sound.

And while some orangutans bite through vines to execute highly unusual Tarzan moves, others appear to have Martha Stewart tendencies, arranging pillows of twigs in unique patterns.

From these varied behaviors, which are each shared by small groups of orangutans, scientists have concluded that the origins of "culture" among primates may go back 14 million years, twice as long as previously estimated.

The discovery also brings the number of species known to have "culture" to a grand total of three: orangutans, chimpanzees and humans. That number may well be larger -- or smaller -- depending on how culture is defined.

According to the scientists' definition, culture is the ability to learn and pass on behaviors from role models in one's immediate community. The behaviors must not be the direct product of biology or habitat -- they are picked up through social contact and imitation.

The research is aimed at understanding how human cultures came about, including the vast array of human languages, dietary preferences, rituals and fashions. Much human activity is clearly tied to cultural practices and influences, but until recently, scientists had been unsure whether that made humans unique. The answer seems to be no.

By closely comparing years of data from six different orangutan communities in Indonesia and Malaysia, scientists said they consistently found that discrete groups exhibited unique behaviors that could not be accounted for by differences in habitat.

Students may respond to following questions in the light of this article;

- From biological perspective, what are the problems?

- What basic knowledge of biology can be used for resolving such problems?

- What kinds of specific information/evidence would you want to "tip the scales" regarding the major issue?

- As a student, what position do you take regarding the issue?

- If you were to take some personal actions regarding these issues, what would they be?

- If you are the chief editor of this Newspaper in which this article appeared, and the one who really decides which article can be published and which one not, what decision would you made and why?

- If you have to re-write this article, how would you re-write it and why?

- What have you learned from actively engaged in this learning activity?

Case 2: In biology classroom of grade 9 through 12 a teacher has students read an article about gene technology. The Boston Globe was provided an article that led Malcolm Ritter to define problems that related to stem cell research. The article discusses the ethical issues about the stem cell research. After reading the article, students discuss the issues about the stem cells research.

Students may discuss the following questions in the light of this article;

- What are the given problems about stem cell research?

- What do you need to know to find solutions?

- Which position would you like to advocate?

- What evidences can you get from the passage?

- If you have to re-write this article, how would you re-write it and why?

- What have you learned from actively engaged in this learning activity? 
Table 2. Stem Cells from 'Dead' Embryo Ethical Problems might be Eased for Opponents

\begin{abstract}
Scientists say they have created a stem cell line from a human embryo that had stopped developing naturally, and so was considered dead. Using such embryos might ease ethical concerns about creating such cells, they suggested.

One specialist said the technique makes harvesting stem cells no more ethically troublesome than organ donation. But others said it still carries scientific and ethical problems.

Scientists want to use human embryonic stem cells to study diseases and create transplant tissue for treating illnesses such as diabetes and Parkinson's disease. Such cells are taken from human embryos that are a few days old, and the harvesting process destroys the embryo. That raises ethical objections.

The new work, published online Thursday by the journal Stem Cells, comes from Miodrag Stojkovic of the Prince Filipe Research Center in Valencia, Spain, with colleagues there and in England.

They studied embryos donated by an in vitro fertilization clinic with consent of the patients. Part of the work focused on 132 arrested embryos, those that had stopped dividing for 24 or 48 hours after reaching various stages of development.

Thirteen of these embryos had developed more than the others, reaching 16 to 24 cells before cell division stopped. Scientists were able to create a stem cell line from just one of these embryos.

These stem cells performed normally on a series of tests, Stojkovic said in a telephone interview.

He said he did not know whether the result indicated a solution to ethical concerns about embryonic stem cells.

The point of the research was to show that such embryos provide an additional source of the cells beyond healthy embryos, rather than to set up any kind of a competition, he said. Both sources should be used, he said.

Dr. Donald W. Landry, director of the division of experimental therapeutics at the Columbia University Medical Center in New York, who proposed the idea of getting stem cells from arrested embryos in 2004, called the work an important addition to the field.

"Regardless of how you feel about personhood for embryos, if the embryo is dead, then the issue of personhood is resolved." Landry said.

"This then reduces the ethics of human embryonic stem cell generation to the ethics of, say, organ donation."

Landry is part of a consortium that is pursuing the approach.

But others said the approach fails to solve the ethical problems.

There is no way to prove that an arrested embryo would have stopped growing if it had been put into a woman's womb rather than a lab dish, said Robin Lovell-Badge of the Medical Research Council's National Institute for Medical Research in London. So that leaves open the possibility that it was the lab conditions that halted their growth, he said.
\end{abstract}

These given cases are examples as socio-scientific issues. In other words, these topics are related with science contents and have sense and importance for society in order to be called as socio-scientific issue [9, 10]. Socio-scientific issues (SSI) are an important context since it enables students to reach reliable data sources and to support their views with scientifically valid evidences [11]. That's why, teaching based on SSI, such as learning through media, provide important advantages for students like increasing in achievement [12], developments in thinking, reasoning and inquiry skills $[13,14]$.

\section{Assessment}

Assessment is one of the crucial parts of learning. Learning through articles published by newspapers may contribute students' conceptual understanding and may enable them to develop their thinking skills. One of the beneficial assessment techniques that can be used at the end of each activity is asking students to re-write the article. They are assessed on how much additional information they added, how accurate information they provided, how they support their views and how they use evidences in their articles. Students' views about the relationship between science, technology and society can be revealed through re-writing activities.

\section{Conclusions}

As these activities demonstrate, advertisements provide a good resource for modeling newspaper in science classroom. Creating a learning environment that leads to discovery of new knowledge requires a deep understanding of the science learning process as embodies in constructivist perspectives. This understanding can be achieved through personal experiences and undertaking searches for evidence for understanding and the relative validity of suggested explanations.

Daily newspapers and popular magazines can be used as sources of information, questions, new topics, issues, and problems for school science teaching and learning. The reports in the newspapers and magazines require certain knowledge and abilities to interpret as they are used. It is desirable to encourage argument among students in a science classes about the claims and use of products. Reports in the popular press can also be used to illustrate the applications of science, particularly in relation to content that relates to local issues. Moreover, they can be used as contexts for developing scientific literacy, particularly in relation to skills and ideas associated with critical thinking about science as a human enterprise, science for citizenship, science for improving decisions related to daily living, and practice for lifelong learning. Scientifically literate person is not learner only for during school term but also s/he is a life-long learner 
[11]. In addition, it is indispensible fact that there are strong relations among science, technology and society. That's why, it would be easier to attract students' attentions for learning through articles in media. All these situations can be used to initiate classroom discussions and to move to more student-centered classrooms.

\section{REFERENCES}

[1] American Association for the Advancement of Science (AAAS). Benchmarks for Science Literacy: A Project 2061 Report, Oxford University Press, New York, 1993.

[2] National Research Council (NRC). National Science Education Standards, National Academy Press, Washington, DC, 1996.

[3] Jarman, R., McClune, B. A survey of the use of newspapers in science instruction by secondary teachers in northern Ireland, International Journal of Science Education, Vol. 24, No. 10, 997-1020, 2002.

[4] Yager, R. E., Penick, J. E. The popular press as a source of information for science instruction, The Hoosier Science Teacher, Vol. 12, No. 4, 1987.

[5] Knowlton, S.R., Barefoot, B. O. Using national newspapers in the college classrooms: Resources to improve teaching and learning, The New York Times, 1999.

[6] Mysliwiec, T. H., Shibley, L., Dunbar, M. E. Using newspapers to facilitate learning, Journal of College Science Teaching, Vol. 33, No. 3, 24-28, 2004.
[7] Bonwell, C. C., Eison, J. A. Active learning: Creating excitement in the classroom, ASHE-ERIC Higher Education Report 1, George Washington University, Washington, DC, USA, 1991.

[8] McSharry, G., Jones, S. Television programming and advertisements: Help or hindrance to effective science education?, International Journal of Science Education, Vol. 24, No. 5, 487-497, 2002.

[9] Eastwood, J. L., Sadler, T. D., Zeidler, D. L., Lewis, A., Amiri, L., Applebaum, S. Contextualizing nature of science instruction in socio scientific issues, International Journal of Science Education, Vol. 34, No.1 5, 2289-2315, 2012.

[10] Topçu, M. S., Muğaloğlu, E. Z., Güven, D. Socio-scientific issues in science education: The case of Turkey, Educational Sciences: Theory \& Practice, Vol. 14, No. 6, 14-22, 2014.

[11] Kapici, H. O, Ilhan, G. O. Pre-service teachers' attitudes toward socio-scientific issues and their views about nuclear power plants, Journal of Baltic Science Education, Vol. 15, No.5, 642-652, 2016.

[12] Wongsri, P., Nuangchalerm, P. Learning outcomes between socio-scientific issues based learning and conventional learning activities, Journal of Social Sciences, Vol. 6, No.2, 240-243, 2010.

[13] Sadleri T. D., Zeidler, D. L. The morality of SSI: Construal and resolution of genetic engineering dilemmas, Science Education, Vol. 88, 513-536, 2004.

[14] Zohar, A., Nemet, F. Fostering students' knowledge and argumentation skills through dilemmas in human genetics, Journal of Research in Science Teaching, Vol. 39, No. 1, 35-62, 2002. 